\title{
Effects of prolonged ethanol intake and malnutrition on rat pancreas
}

J M López, J A Bombi, R Valderrama, A Giménez, A Parés, J Caballería, S Imperial, $S$ Navarro

\begin{abstract}
Nutritional factors, especially the protein and fat content of the diet, may change pancreatic morphology after ethanol induced injury. This study was performed to delineate the combined effects of a low fat diet and longterm ethanol ingestion on the rat pancreas. Male Sprague-Dawley rats were maintained with five different diets for 12 weeks and the pancreas removed on the day they were killed. Rats fed a very low fat diet without ethanol $(5 \%$ of total calories as lipid) developed malnutrition, pancreatic steatosis, and reduction in zymogen granules content. Animals fed a $35 \%$ lipid diet with ethanol also developed pancreatic steatosis but changes in zymogen granules content were not detected. Both malnutrition and longterm ethanol consumption increased pancreatic cholesterol ester content, and their effects were additive. Pancreatic steatosis was accompanied with hypercholesterolaemia. Amylase, lipase, and cholesterol esterase content were reduced in malnourished rats; but longterm ethanol ingestion, regardless of the nutritional state, increased lipase content and decreased amylase. It is suggested that high serum cholesterol concentrations and increased pancreatic lipase activity could cause accumulation of cholesterol esters in acinar cells. Fat accumulation in the pancreas has been reported as the earliest histopathological feature in alcoholic patients and may be responsible for cytotoxic effects on the acinar cells at the level of the cell membrane. Although it is difficult to extrapolate results in this animal study to the human situation, the results presented in this work might explain the higher incidence of pancreatitis is malnourished populations as well as in alcoholic subjects that is reported in dietary surveys.

(Gut 1996; 38: 285-292)
\end{abstract}

Keywords: ethanol, rat, pancreas, malnutrition.

Department of Biochemistry and Physiology

S Imperial

University of Barcelona, Barcelona, Spain

Correspondence to: Dr S Navarro, Gastroenterology Service, Hospital Clínic i Provincial, c/Villarroel 170, 08036 Barcelona, Spain.

Accepted for publication 9 August 1995

The role of nutrition in the pathogenesis of alcoholic pancreatitis remains controversial, because dietary surveys in different countries have produced conflicting results. In Europe, Japan, chronic pancreatitis is mostly seen in male patients drinking more than $100 \mathrm{ml}$ pure alcohol per day and having a high fat and high protein diet. ${ }^{12}$ In contrast, alcoholic pancreatitis has been reported to occur in malnourished subjects ${ }^{3}$ and calcifying pancreatitis (in the absence of alcoholism) is common in tropical areas: India, Africa, and South East Asia, where malnutrition is prevalent. ${ }^{4}$ The possible causes for tropical pancreatitis that have been most commonly suggested are kwashiorkor (protein insufficiency in childhood) ${ }^{5}$ and cassava consumption. ${ }^{7}$ In addition, rats fed protein deficient diets develop pancreatic steatosis, acinar cell atrophy, and a diminution in the number of zymogen granules. ${ }^{8-10}$ It is not clear, however, whether protein malnutrition is the sole aetiological factor. There are many parts of India where protein intake is low but pancreatitis does not occur. In the South Indian State of Kerala, which has the highest known frequency of chronic pancreatitis, the diet is characterised by a moderately low protein intake and a very low fat intake. ${ }^{11}$ There might be some mechanism common with the alcoholic form of chronic pancreatitis, inasmuch as the biochemical composition of Indian and European calculi is similar. ${ }^{12}$ The purpose of this study was to examine the combined effects of longterm alcohol intake and very low fat ingestion on rat pancreatic morphology using a liquid diet feeding model for strict nutritional control. In addition, as fat accumulation in acinar cells has been reported to be the earliest histopathological feature in the pancreas of alcoholic patients ${ }^{13}$ and in experimental animals ${ }^{14}$ pancreatic lipid composition was also analysed in the rats.

\section{Methods}

\section{Animals and experimental diets}

Male rats of Sprague-Dawley strain (Charles River Breeding Laboratories, Wilmington, MA) were maintained with A04 PANLAB solid diet and tap water until they reached a weight of 200-250 g. The animals were then divided in five groups, housed in individual cages, and fed for 12 weeks the following diets:

Solid diet - A04 PANLAB diet ad libitum (group $\mathrm{A}, \mathrm{n}=11$ ).

Liquid diets $-35 \%$ lipid diet without ethanol (group $\mathrm{B}, \mathrm{n}=7$ ), 35\% lipid diet with ethanol (group $\mathrm{C}, \mathrm{n}=7$ ), $5 \%$ lipid diet without ethanol North and Latin America, South Africa, and (group $\mathrm{D}, \mathrm{n}=7$ ), and $5 \%$ lipid diet with ethanol (group $\mathrm{E}, \mathrm{n}=7$ ).

Table I gives the compositions of these diets. Dietary composition of liquid diets was based on the general formulation of Lieber and De Carli. ${ }^{16}$ Energy density was $1000 \mathrm{kcal} / \mathrm{l}$. amounts of vitamins and minerals as described Diets were supplemented with regular 
TABLE I Dietary composition (per cent of total energy)

\begin{tabular}{llllc}
\hline Diet & Protein & Lipid & Carbohydrate & Ethanol \\
\hline Ad libitum (A) & 30 & 12 & 58 & 0 \\
Control 35\% of lipids (B) & 18 & 35 & 47 & 0 \\
Alcoholic 35\% of lipids (C) & 18 & 35 & 11 & 36 \\
Control 5\% of lipids (D) & 18 & 5 & 77 & 0 \\
Alcoholic 5\% of lipids (E) & 18 & 5 & 41 & 36 \\
\hline
\end{tabular}

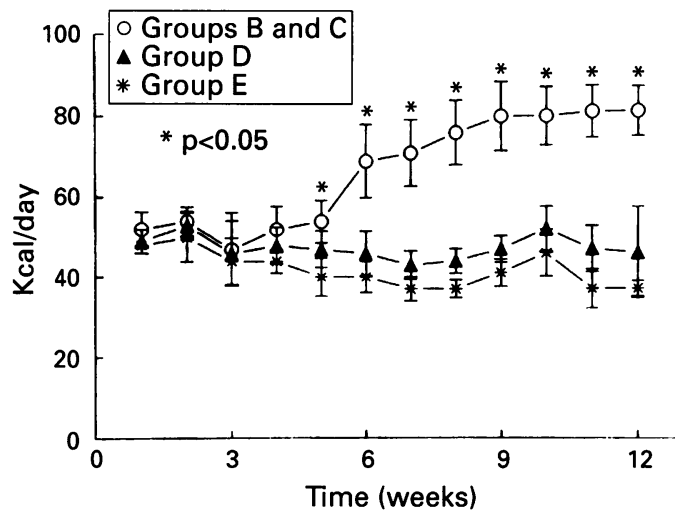

Figure 1: Daily caloric intake over the 12 week period. Values are mean (SD) of findings in seven rats of each group. The $p$ value shown on the graph was determined using the Newman-Keuls test.

previously. ${ }^{16}$ In group $\mathrm{C}$ ethanol was given as $3 \%$ concentration (w/v) on the first two days, $4 \%(\mathrm{w} / \mathrm{v})$ on the third and fourth days, and $5 \%$ $(w / v)$ thereafter. These animals were rate limiting and had the lowest spontaneous food intake in the first three weeks. The amounts of liquid diet given to the other animals were accordingly adjusted each day so that each animal received the same amount of liquid diet over the feeding period. On the day before death, animals received their liquid diets in divided portions. Administration of diets in divided portions was necessary to ensure equal rates of food consumption before death. Rats fed 35\% lipid diet without ethanol (group B) tended to consume their diet during the three to 12 hours after administration. In contrast, the animals fed the other diets consumed them throughout a 24 hour feeding period. Accordingly, on the day before death, animals received half of their usual portion at 1200 and the remaining half at 1800 . On the following morning they were killed under ether anaesthesia by exsanguination via a cardiac puncture. The pancreas was quickly removed, trimmed of adipose tissue, and weighed. Small samples were taken for light and electron microscopy and the rest of the gland was frozen immediately at $-70^{\circ} \mathrm{C}$. Light microscopic examination of the debrided pancreas showed no evidence of adipose or connective tissue contamination. Blood was collected from all animals via cardiac puncture and serum aliquots were frozen at $-20^{\circ} \mathrm{C}$.

\section{Pancreatic juice collection}

Pancreatic juice from male Sprague-Dawley rats (500 g of body weight) maintained with A04 PANLAB solid diet and tap water was collected. The common bile duct was cannulated close to the duodenum and the duct was ligated at the hepatic hilum. Pancreatic secretion was stimulated by sequential administration of secretin (4 U/kg bw) and cholecystokinin (CCK) (4 U/kg bw) into the jugular vein for 80 minutes using an infusion pump $(0.5 \mathrm{ml} / \mathrm{min})$. Pancreatic juice was collected on ice for two hours. Human pancreatic juice was collected without previous stimulation of pancreatic secretion by catheterisation of the pancreatic duct from patients after either gastric or colonic surgery. To prevent proteolysis, proteinase inhibitors (aprotinin $35 \mu \mathrm{g} / \mathrm{ml}, 2 \mathrm{mM}$ benzamidine, and $5 \mathrm{mM} \epsilon$-aminocaproic acid) were added to rat and human pancreatic juices, which were then lyophilised and stored at $-70^{\circ} \mathrm{C}$.

\section{SDS-PAGE and western blot analysis}

SDS-PAGE was performed according to the method of Laemmli. ${ }^{17}$ Gels were either stained with $0 \cdot 1 \%(\mathrm{w} / \mathrm{v})$ Coomassie Brilliant Blue or capillary transferred to nitrocellulose membranes. Immunodetection in nitrocellulose replicas was done with a rabbit polyclonal antiserum against human cholesterol esterase (pAs L64) diluted $1 / 100$ in $1 \%$ bovine serum albu$\mathrm{min}$, and antirabbit IgG peroxidate conjugate (Sigma) diluted $1 / 10000$ in $1 \%$ bovine serum albumin. Development was performed with 4Chloro-1-Naphthol $(0.5 \mathrm{mg} / \mathrm{ml})$ in phosphate buffered saline pH $7 \cdot 2$ (PBS), $15 \%$ methanol, $0.01 \%$ hydrogen peroxide (v/v) for 20 minutes. Membranes were washed with distilled water, dried, and stored in the dark.

\section{Morphological studies}

Samples from the duodenal portion of the pancreas were removed at the time of death and fixed in $2.5 \%$ glutaraldehyde solution ( $\mathrm{pH}$ $7 \cdot 4$ ) at $4^{\circ} \mathrm{C}$ for 12 hours for ultrastructural study. The tissue was postfixed in $2 \% \mathrm{OsO}_{4}$ and embedded in epoxy resin after dehydration. Thin sections $(1 \mu \mathrm{m})$ were stained with Richardson dye solution. After uranyl acetate and lead citrate staining, ultrathin sections (60 $\mathrm{nm}$ ) were examined using a Zeiss 109 Turbo

TABLE II Effect of the five diets on body weight, weight change, pancreatic weights, and pancreatic protein content ${ }^{\star}$

\begin{tabular}{|c|c|c|c|c|c|}
\hline & $\begin{array}{l}\text { Ad libitum } \\
(A)\end{array}$ & $\begin{array}{l}\text { Control } \\
35 \% \text { lipids (B) }\end{array}$ & $\begin{array}{l}\text { Alcoholic } \\
\text { 35\% lipids (C) }\end{array}$ & $\begin{array}{l}\text { Control } \\
5 \% \text { lipids (D) }\end{array}$ & $\begin{array}{l}\text { Alcoholic } \\
5 \% \text { lipids (E) }\end{array}$ \\
\hline $\begin{array}{l}\text { Initial weight }(\mathrm{g}) \\
\text { Final weight }(\mathrm{g}) \dagger \\
\text { Weight change }(\%) \dagger \\
\text { Pancreatic weight }(\mathrm{g}) \dagger \\
\text { Pancreatic weight }(\mathrm{g} / 100 \mathrm{~g} \text { body weight }) \ddagger \\
\text { Pancreatic protein content }(\mathrm{mg} / \mathrm{g}) \dagger\end{array}$ & $\begin{array}{c}190 \cdot 3(4 \cdot 4) \\
510 \cdot 8(32 \cdot 3) \\
+168 \cdot 3(13 \cdot 7) \\
1 \cdot 15(0 \cdot 13) \\
0 \cdot 23(0 \cdot 03) \\
201 \cdot 3(13 \cdot 0)\end{array}$ & $\begin{array}{r}263 \cdot 0(19 \cdot 2) \\
389 \cdot 8(33 \cdot 1) \\
+48 \cdot 8(14 \cdot 2) \\
1 \cdot 01(0 \cdot 16) \\
0 \cdot 26(0 \cdot 03) \\
189 \cdot 7(8 \cdot 6)\end{array}$ & $\begin{array}{c}251 \cdot 0(10 \cdot 4) \\
404 \cdot 4(32 \cdot 7) \\
+61 \cdot 1(10 \cdot 7) \\
0 \cdot 97(0 \cdot 17) \\
0 \cdot 24(0 \cdot 04) \\
190 \cdot 4(11 \cdot 2)\end{array}$ & $\begin{array}{l}258 \cdot 1(7 \cdot 0) \\
173 \cdot 0(9 \cdot 5) \\
-32 \cdot 9(3 \cdot 8) \\
0 \cdot 51(0 \cdot 10) \\
0 \cdot 29(0 \cdot 08) \\
146 \cdot 7(19 \cdot 0)\end{array}$ & $\begin{array}{l}256 \cdot 8(8 \cdot 6) \\
161 \cdot 6(17 \cdot 0) \\
-37 \cdot 1(5 \cdot 8) \\
0.57(0 \cdot 16) \\
0.35(0 \cdot 08) \\
156 \cdot 3(14 \cdot 2)\end{array}$ \\
\hline
\end{tabular}

*Values are mean (SD) for 11 animals of group $A$ and seven animals of groups B, C, D, E

tMalnutrition effect: B-D, C-E, p <0.05. ‡Ethanol effect: D-E, $p<0.05 ;$ malnutrition effect: C-E, $p<0.05$. 
TABLE III Effect of the five diets on serum albumin, cholesterol, triglycerides, and amylase values ${ }^{\star}$

\begin{tabular}{|c|c|c|c|c|c|}
\hline & $\begin{array}{l}\text { Ad libitum } \\
(A)\end{array}$ & $\begin{array}{l}\text { Control } \\
35 \% \text { lipids (B) }\end{array}$ & $\begin{array}{l}\text { Alcoholic } \\
35 \% \text { lipids (C) }\end{array}$ & $\begin{array}{l}\text { Control } \\
5 \% \text { lipids (D) }\end{array}$ & $\begin{array}{l}\text { Alcoholic } \\
5 \% \text { lipids (E) }\end{array}$ \\
\hline Albumin $(\mathrm{g} / \mathrm{l}) \dagger$ & $36 \cdot 7(1 \cdot 3)$ & $33 \cdot 1(2 \cdot 3)$ & $30 \cdot 9(1.8)$ & $27 \cdot 0(2 \cdot 3)$ & $27 \cdot 7(3 \cdot 6)$ \\
\hline Cholesterol $(\mathrm{mg} / \mathrm{dl}) \ddagger$ & $51.9(10.7)$ & $70 \cdot 1(6 \cdot 9)$ & $122 \cdot 7(27 \cdot 7)$ & $90 \cdot 4(17 \cdot 4)$ & $115.9(21 \cdot 1)$ \\
\hline Triglycerides $(\mathrm{mg} / \mathrm{dl}) S$ & $70 \cdot 2(16 \cdot 2)$ & $48.9(13.5)$ & $105 \cdot 4(64 \cdot 2)$ & $42 \cdot 3(14 \cdot 3)$ & $32 \cdot 6(9 \cdot 9)$ \\
\hline Amylase $(\mathrm{U} / \mathrm{l})$ & $4249(446)$ & $5421(391)$ & $5550(607)$ & $4031(635)$ & $4633(357)$ \\
\hline
\end{tabular}

*Values are mean (SD) for 11 animals of group A and seven animals of groups B, C, D, E.

† Malnutrition effect: B-D, C-E, p $<0.05$; solid diet effect A-B, $\mathrm{p}<0.05$.

łEthanol effect: B-C, D-E, p < 0.05; malnutrition effect: B-D, p<0.05; solid diet effect: A-B, $p<0.05$

\$Ethanol effect: $\mathrm{B}-\mathrm{C}, \mathrm{p}<0.05$; malnutrition effect: $\mathrm{C}-\mathrm{E}, \mathrm{p}<0.05$.

$\|$ Malnutrition effect: B-D , C-E, $p<0.05$; solid diet effect: $A-B, p<0 \cdot 05$.

electron microscope. For light microscopy, other sections of the pancreas were fixed in $10 \%$ buffered formalin $(\mathrm{pH} 7 \cdot 4)$, processed in paraffin wax, and stained with haematoxylin and eosin.

\section{Biochemical measurements}

Albumin, tryglyceride, cholesterol, and amylase values in serum were measured by the methods of Doumas et al, ${ }^{18}$ Fossati and Precipe, ${ }^{19}$ Allain et al, ${ }^{20}$ and Sarber et al,,$^{21}$ respectively. Amylase and lipase activities were assayed in homogenised tissue by the methods of Sarber et $a l^{21}$ and Ziegenhorn et $a l^{22}$ respectively. Protein was determined as described by Lowry et $a^{23}$ using bovine serum albumin as the standard. Pancreatic lipids were extracted according to the method of Folch et al. ${ }^{24}$ Lipids were separated by thin layer chromatography on
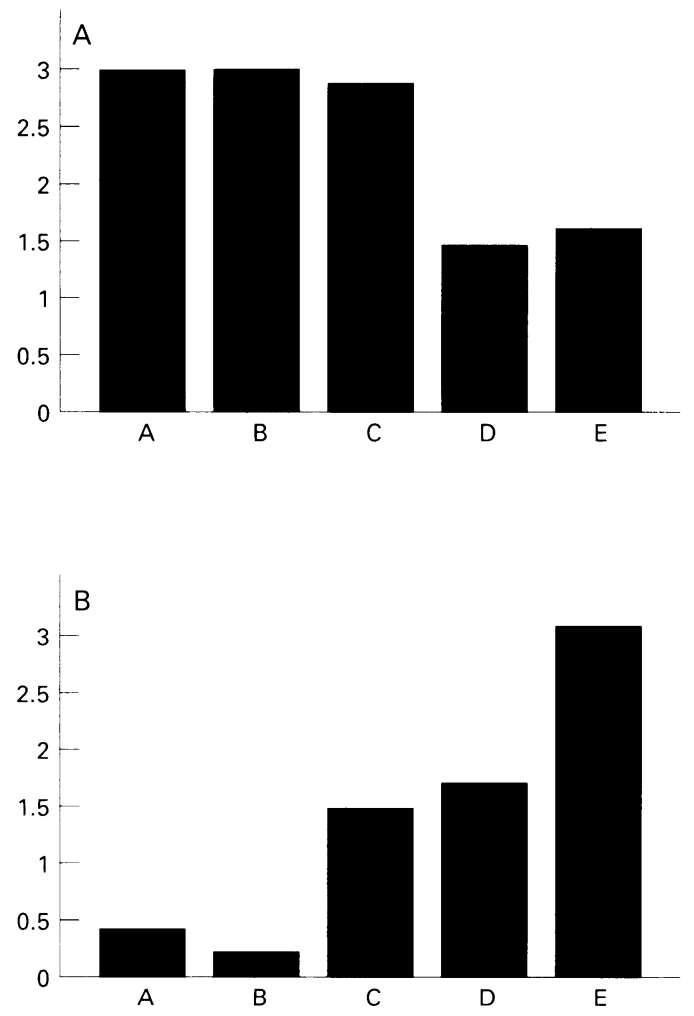

Figure 2: Zymogen granules and lipid droplets in pancreatic tissue. (A) Effect of the five diets on zymogen granules content in the pancreas. (B) Effect of the five diets on lipid droplets content in the pancreas. Zymogen granules and lipid droplets were determined from thin sections $(1 \mu \mathrm{m})$ of pancreatic tissue and graded as follows: zymogen granules: $+(1),+1++(1 \cdot 5),++(2),+++(3)$. Lipid droplets: $(0),-1+(0 \cdot 5),+(1),+1++(1 \cdot 5),++(2),+++(3)$. Numeric values (in parenthesis) are given to facilitate the evaluation of the data. Results are mean of findings in seven rats of each group. silica gel $60 \mathrm{~F}_{254} 20 \times 20 \mathrm{~cm}$ of $0.25 \mathrm{~mm}$ thickness (Merck) with a solvent mixture of petroleum ether-diethyl ether-glacial acetic acid $(85: 15: 1 \mathrm{v} / \mathrm{v} / \mathrm{v})$. Measured amounts of standards for each lipid class were mixed together and spotted besides the sample. Lipid bands on the plate were detected by iodine vapours and scraped off from the plate after the brown colour had faded. Silica gels were extracted with chloroform for analysis of free and esterified cholesterol, with chloroform-methanol $(2: 1 \mathrm{v} / \mathrm{v})$ for triglycerides, and with chloroformmethanol-ammonium hydroxide (65:35:5 $\mathrm{v} / \mathrm{v} / \mathrm{v})$ for phospholipids. Triglycerides were determined by the method described by Fossati and Precipe, ${ }^{19}$ free and ester cholesterol by the $o$-phthalaldehyde method, ${ }^{25}$ and phospholipid phosphorus according to Fiske and Subbarow. ${ }^{26}$

\section{Statistical analysis}

Data were expressed as means (SD) and were analysed by analysis of variance (ANOVA). In parameters found to be significant by ANOVA, group means were compared using the Newman-Keuls test. Values of $p<0.05$ were considered to be statistically significant. An effect of solid diet was considered to be present when analysis showed that animals fed a A04 PANLAB solid diet (group A) were different from those fed a liquid diet with $35 \%$ lipids (group B). An ethanol effect was considered to be present when animals fed a 35\% lipid diet with ethanol (group C) were different from those fed a control diet (group B) or when animals fed a 5\% lipid alcoholic diet (group E) were different from those fed a 5\% lipid diet without ethanol (group D). A malnutrition effect was considered to be present when animals fed a 5\% lipid diet (group D) were different from those fed a 35\% lipid diet (group B) or when animals fed a 5\% lipid alcoholic diet (group E) were different from those fed a $35 \%$ lipid alcoholic diet (group C).

\section{Results}

Animals fed a solid diet (group A) and 35\% lipid diets (groups B and C) seemed healthy and increased their body weight over the feeding period. In contrast, those fed $5 \%$ lipid diets (groups D and E) lost weight and exhibited hair loss. Animals fed liquid diets received the same number of calories over the three week period, but after the third week rats fed a $5 \%$ lipid diet tended to consume less calories per day than those receiving a $35 \%$ lipid diet (Fig 


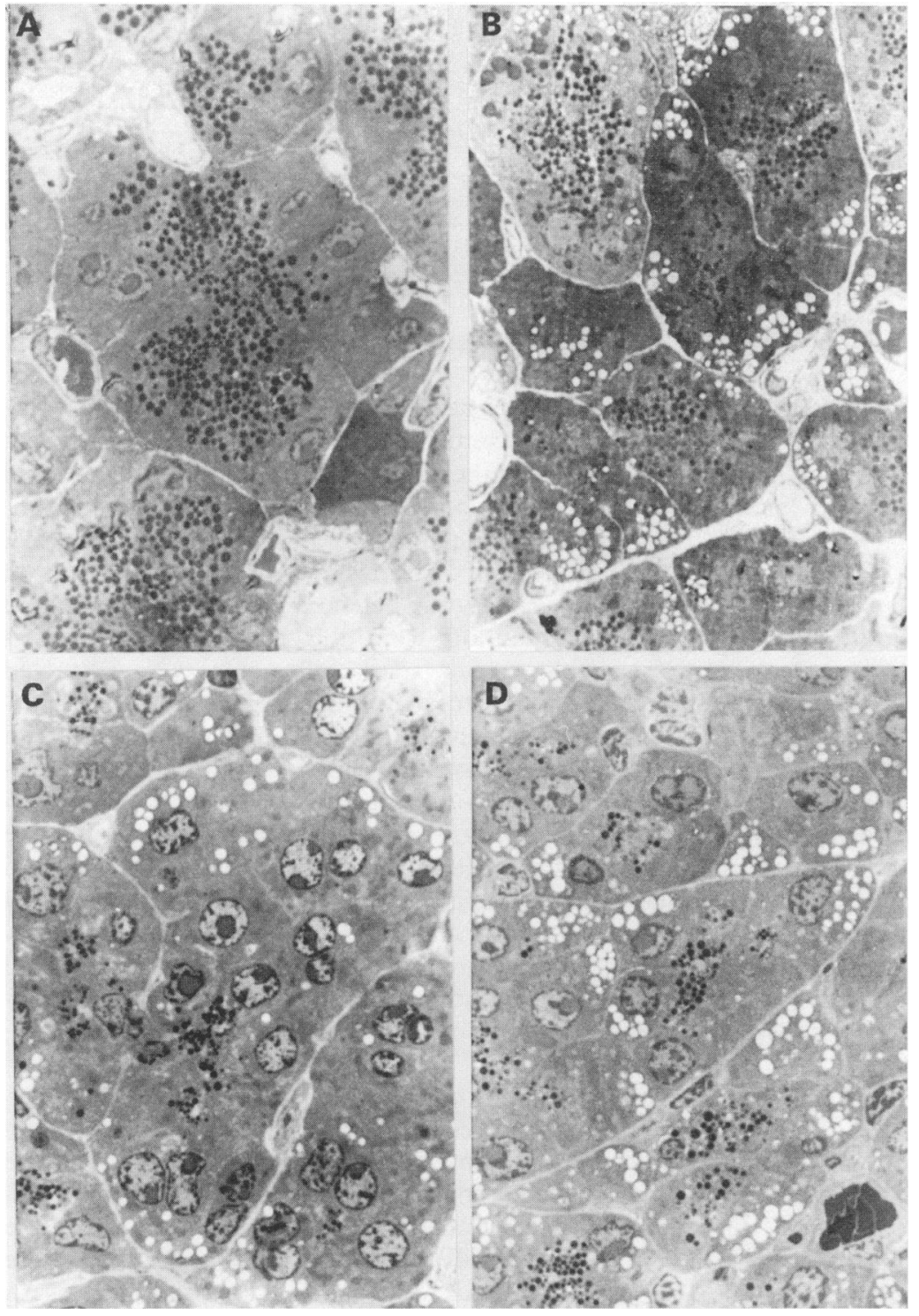

Figure 3: Epoxy resin thin sections of pancreatic acinar cells showing accumulation of lipid droplets in the pancreas of rats fed the $35 \%$ lipid diet with ethanol (B) compared with animals fed the 35\% lipid diet without ethanol $(A)$. Lipid droplets accumulation and pronounced reduction of zymogen granules were seen in rats fed the $5 \%$ lipid diet without ethanol $(C)$ or the $5 \%$ lipid diet with ethanol $(D)$. Richardson blue stain $(\times 1500)$.

1). Final body weight and absolute pancreatic weight were decreased in animals fed 5\% lipid diets (Table II). When corrected for differences in body weight, however, a stimulatory effect of alcohol feeding on pancreatic weight became apparent in group E. Pancreatic protein content of rats fed the $5 \%$ lipid diets was only $75-80 \%$ of the values seen in the animals fed the $35 \%$ lipid diets.

\section{Serum measurements}

Albumin values for animals fed the 5\% lipid diets (groups D and E) were less than $31 \mathrm{~g} / 1$, reflecting the malnutrition process induced in these groups, whereas values for the rest of the animals were between 29 and $39 \mathrm{~g} / \mathrm{l}$. Longterm ethanol feeding, regardless of the lipidic content of the diet, increased serum cholesterol concentrations (Table III). Animals fed the 5\% lipid diet without ethanol had higher cholesterol concentrations than those which received the $35 \%$ lipid diet without ethanol (malnutrition effect). Serum concentrations of triglycerides were the highest in alcoholic rats fed a 35\% lipid diet (group $\mathrm{C}$ ) with a wider standard deviation. Amylase values in rats fed the 35\% lipid diets were higher than those in the other groups.

\section{Pancreatic morphology}

Light microscopy - none of the animals developed morphological evidence of pancreatitis, such as fibrosis, protein plugs, or focal collection of inflammatory cells. Figure 2 summarises the determination of lipid droplets and zimogen granules in the five groups of animals. Pancreatic acinar cells of rats fed the $35 \%$ lipid diet without ethanol (group B) showed a normal morphology (Fig 3A), whereas animals fed the $35 \%$ lipid diet with ethanol (group C) showed lipid droplets accumulation (Fig 3B). Malnutrition (groups D and E) induced accumulation of lipid droplets in acinar cells being more striking in the alcoholic group (E) (Fig 3C, D). A pronounced reduction in the number of zymogen granules was seen in sections of both malnourished groups ( $D$ and E) compared with groups B and C.

Electron microscopy - on electron microscopic examination, intracellular fat droplets were also seen in the acinar cells of animals fed a $35 \%$ lipid diet with ethanol (group C) and in those fed the low fat diets (groups D and E) (Fig 4). Fat droplets were located in the basal pole of the acinar cells. No changes were apparent in the mitochondria or in the endoplasmic reticulum. No fat droplets were seen in sections from animals fed a solid diet (group A) or a $35 \%$ lipid diet without ethanol (group B) (Fig 4A). Also at the ultrastructural level, diminution in the number of zymogen granules was seen in tissue from malnourished animals in agreement with findings from light microscopy (Fig 4C, D).

\section{Pancreatic lipid content}

Both malnutrition and prolonged ethanol administration were associated with higher values of pancreatic cholesterol ester, and these effects seemed to be additive, with the animals fed the $5 \%$ lipid diet plus ethanol exhibiting the highest values (Table IV). In addition, malnutrition was associated with higher concentrations of phospholipids. No significant differences were seen in cholesterol and triglycerides values. The number of lipid droplets measured from thin sections showed a clear correspondence with cholesterol ester content in the pancreas (Fig 5).

\section{Amylase and lipase activities}

Both amylase and lipase activities (expressed as $\mathrm{U} / \mathrm{mg}$ protein or as $\mathrm{U} / \mathrm{g}$ pancreas) were reduced in rats fed the $5 \%$ lipid diets (malnourished animals). On the other hand, longterm ethanol feeding, regardless of the lipid content of the diets, caused decreased amylase activity and increased lipase activity (Table V). 

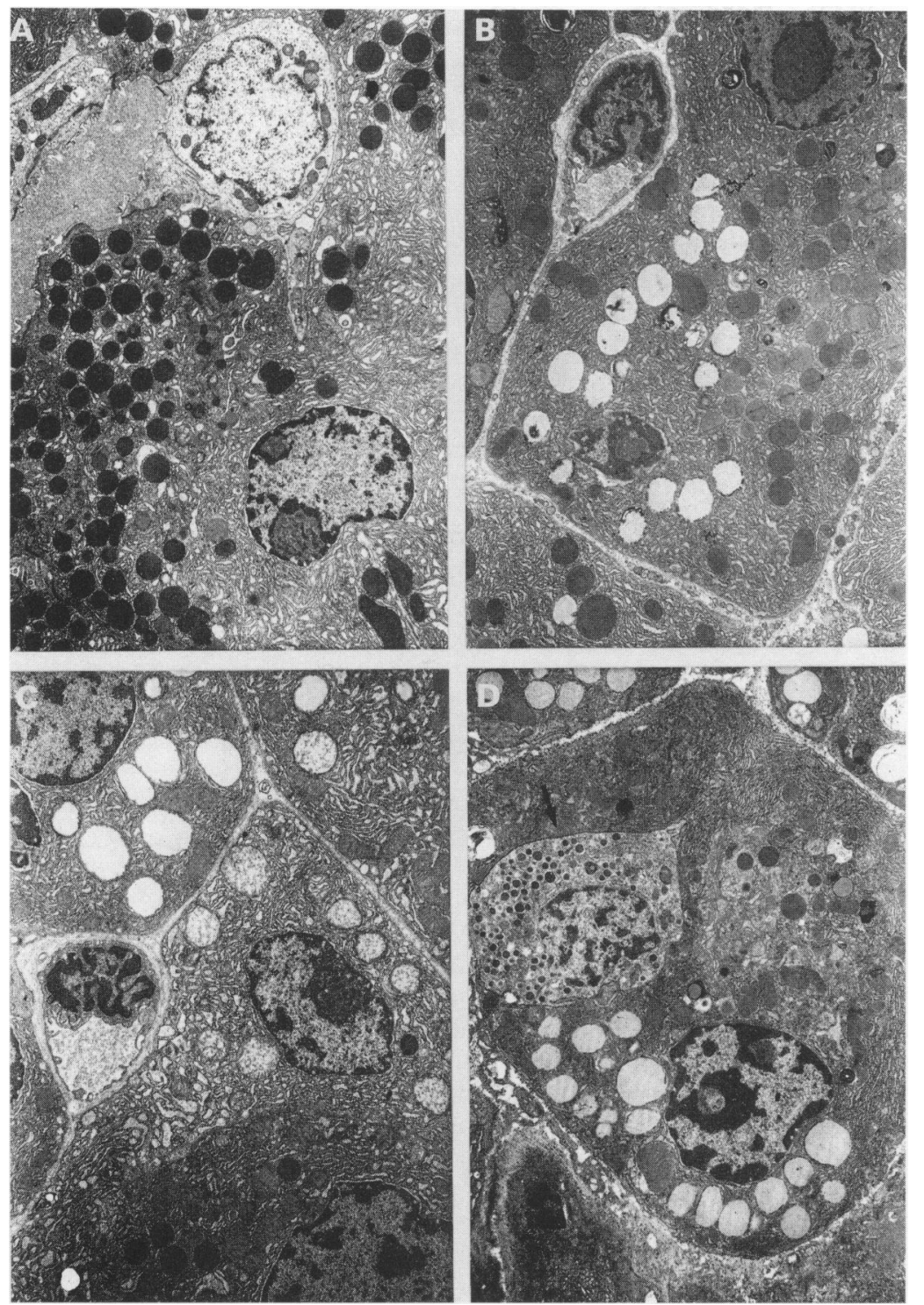

Figure 4: Electronmicrographs of rat pancreatic cells. (A) 35\% lipid diet without ethanol. (B) $35 \%$ lipid diet with ethanol. (C) $5 \%$ lipid diet without ethanol. (D) $5 \%$ lipid diet with ethanol. Lipid droplets are located at the basal pole of the acinar cells. In (D) an endocrine cell (arrow) with normal morphology is shown next to an acinar cell with multiple fat droplets. Uranyl acetate and lead citrate staining (×9000).

Amylase, lipase, and cholesterol esterase content Figure 6 illustrates the qualitative distribution of pancreatic proteins in the five groups of rats. Animals fed the 5\% lipid diet (groups D and E, Fig 6D, E) showed a decreased amylase and lipase content than rats fed the $35 \%$ lipid diet (groups B and C, Fig 6B, C). Ethanol feeding (groups $\mathrm{C}$ and $\mathrm{E}$ ) produced a decrease of amylase and an increase of lipase content in rat pancreas with regard to control animals (groups B and D, respectively). No differences were seen in the banding pattern of rats fed the solid diet (group A) and the 35\% lipid diet without ethanol (group B) (Fig 6A, B). These results are in agreement with the amylase and lipase activities measured in the five groups (Table V).

Cholesterol esterase content was determined in rat pancreatic extracts by western blot analysis. Polyclonal antiserum (pAs L64) against human cholesterol esterase showed cross reaction with rat cholesterol esterase in nitrocellulose blots of pancreatic juices (Fig 7, right). Human cholesterol esterase showed an immunostained band at approximately $\mathrm{Mr} 100$ 000 and rat cholesterol esterase at $\mathrm{Mr} 69000$. Both proteins are visible in the Coomassie stained counterpart (Fig 7, left). Nitrocellulose blots of pancreatic extracts of malnourished rats (groups D and E) (Fig $8 \mathrm{E}, \mathrm{F}$ ) showed a cholesterol esterase band $(69 \mathrm{kDa})$ less stained than that of the animals fed the $35 \%$ lipid diets (groups B and C) (Fig 8G, H).

\section{Discussion}

This study was conducted in Sprague-Dawley rats to investigate the combined effects of a low fat diet and prolonged ethanol ingestion on rat pancreas. Administration of a liquid diet for 12 weeks providing $5 \%$ of the chemical energy as fat, $18 \%$ as protein, and $77 \%$ as carbohydrates resulted in a pronounced malnutrition of the rats, which was evident after three weeks of feeding (reduction in $-27 \%$ of the initial body weight). Malnutrition seen could be caused by a deficiency of essential fatty acids in the diet. It has been described that insufficient linoleic acid intake induces growth reduction and skin lessions on the rat. ${ }^{27} 28$ Previous studies in rats feeding 5\% lipid diets did not show a malnutrition effect. ${ }^{29} 30$ These differences could be explained by variations in the essential fatty acid content of the diets. In the 5\% lipid diet given in our study, linoleic acid and linolenic acid represented $1 \cdot 1 \%$ and $0.4 \%$ of total calories, respectively. ${ }^{31}$ In general, values of essential fatty acids below $3 \%$ of total calories are considered to be deficient. ${ }^{28} 32$ There is no evidence of essential fatty acid deficiency causing pancreatitis in the human, but experimental studies have suggested a decreased resistance of the pancreas to injury by trypsin or bile ingestion. ${ }^{33}$ The potential role of essential fatty acid deficiency in pancreatic injury is a new concept that needs further study.

Administration of 5\% lipid diets (groups D and $\mathrm{E})$ resulted in a pronounced accumulation of lipid droplets and a diminution in the number of zymogen granules in pancreatic acinar cells. Those morphological changes were confirmed by biochemical measurements in the

TABLE IV Effect of the five diets on the lipid composition of pancreatic tissue in Sprague-Dawley rats

\begin{tabular}{|c|c|c|c|c|c|}
\hline & $\begin{array}{l}\text { Ad libitum } \\
(A)\end{array}$ & $\begin{array}{l}\text { Control } \\
35 \% \text { lipids (B) }\end{array}$ & $\begin{array}{l}\text { Alcoholic } \\
35 \% \text { lipids (C) }\end{array}$ & $\begin{array}{l}\text { Control } \\
5 \% \text { lipids (D) }\end{array}$ & $\begin{array}{l}\text { Alcoholic } \\
5 \% \text { lipids (E) }\end{array}$ \\
\hline Cholesterol esters $†$ & $0 \cdot 37(0 \cdot 10)$ & $0.46(0.13)$ & $1.96(0.44)$ & $3.57(1.52)$ & $6.59(1.34)$ \\
\hline Triglycerides & $1.89(1.43)$ & $1.45(1.12)$ & $2.33(1.67)$ & $1.25(0.70)$ & $2.72(1.81)$ \\
\hline Cholesterol & $1 \cdot 11(0 \cdot 17)$ & $1.15(0.34)$ & $1.16(0.31)$ & $1 \cdot 11(0 \cdot 27)$ & $1 \cdot 13(0 \cdot 10)$ \\
\hline Phospholipids $\ddagger$ & $15.73(2.73)$ & $16.48(3.38)$ & $14.53(3.16)$ & $19 \cdot 69(2 \cdot 07)$ & $19 \cdot 42(4 \cdot 78)$ \\
\hline
\end{tabular}

*Values are mean (SD) for 11 animals of group $A$ and seven animals of groups $B, C, D, E$.

†Ethanol effect: B-C, D-E, p <0.05; malnutrition effect: B-D, C-E.

$\neq$ Malnutrition effect: $\mathrm{C}-\mathrm{E}, \mathrm{p}<0.05$. 


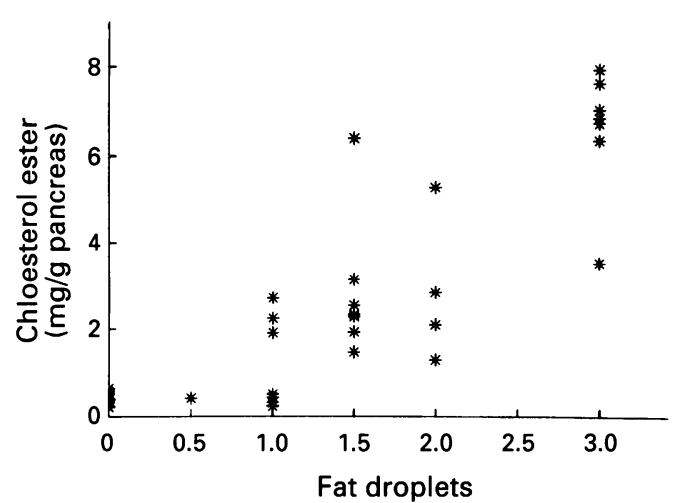

Figure 5: Correlation of the acinar lipid droplets, determined by light microscopy study, and the cholesterol ester content in rat pancreas.

pancreas, and the number of lipid droplets showed a clear correspondence with the content of cholesterol esters (Fig 5). Malnutrition decreased lipase and amylase activities in pancreatic tissue, while ethanol administration increased lipase activity and decreased amylase activity. Low amylase activities in alcoholic rats (Table V) agrees with previously published reports ${ }^{34}$ and represents an adaptation to the low carbohydrate content of alcoholic diets. Moreover, it has been described that ethanol feeding, regardless of the carbohydrate composition of the diets also causes pancreatic amylase reduction. ${ }^{35}$ The increased lipase activity in alcoholic rats could represent a metabolic adaptation to longterm ethanol ingestion, because pancreatic lipase is able to metabolise ethanol through a non-oxidative pathway. ${ }^{36}$

The differences seen in enzymatic activities were confirmed after qualitative analysis of pancreatic proteins in SDS-PAGE stained with Coomassie Brilliant blue (Fig 6). Western blot analysis showed that pancreatic cholesterol esterase was decreased in malnourished rats (Fig 8) in agreement with a reduction in the number of zymogen granules seen in the morphological study.

Cholesterol ester accumulation in acinar cells has been reported in rats fed a 35\% lipid diet with ethanol for three weeks ${ }^{14}$ and for 21 months. ${ }^{15}$ Moreover, rats fed a protein deficient diet for four weeks developed pancreatic steatosis with a high level of cholesterol esters in the pancreas. ${ }^{10}$ This study shows, for the first time, that administration of a very low fat diet for 12 weeks induces cholesterol ester deposition in the rat pancreas and that this effect is increased by ethanol feeding. Pancreatic phospholipids were also increased in malnourished animals but an ethanol effect was not seen. It seems probable that the lipid

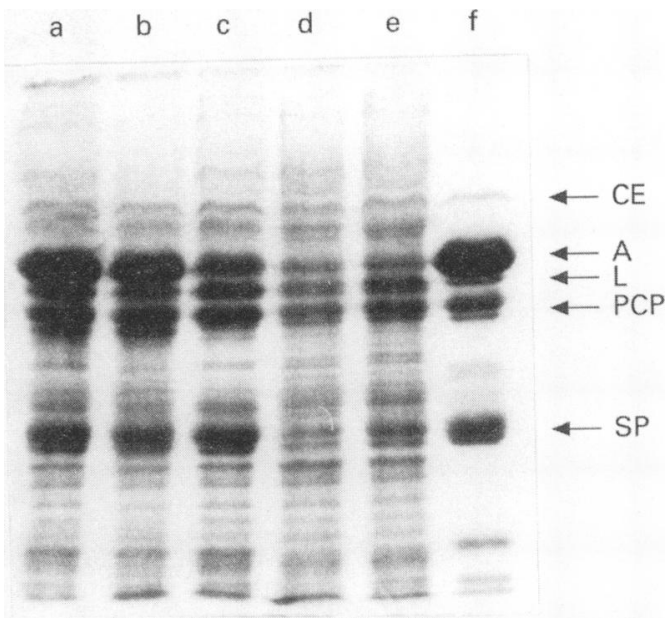

Figure 6: SDS-PAGE of rat pancreatic tissue. Rat pancreas was homogenised in $500 \mu l$ of phosphate buffered saline pH 7.2 with proteinase inhibitors (aprotinin 14 $\mu \mathrm{g} / \mathrm{ml}, 1 \mathrm{mM}$ benzamidine, $0.2 \mathrm{mM}$ PMSF), and spun at $12000 \mathrm{~g}$ for 15 minutes at $4^{\circ} \mathrm{C}$. The supernatant was collected and samples ( $32 \mu \mathrm{g}$ of protein) were analysed on $12 \%$ polyacrylamide gel stained with Coomassie: (a) rat pancreas of group $A$, (b) rat pancreas of group $B$, (c) rat pancreas of group $C,(d)$ rat pancreas of group $D,(e)$ rat pancreas of group $E$. Secretory proteins from rat pancreatic juice (18 $\mu \mathrm{g}$ of protein) were separated by SDS-PAGE and used as markers $(f)$. Cholesterol esterase, amylase, lipase, procarboxypeptidases, and serine proteases are shown as $C E, A, L, P C P$, and $S P$, respectively.

droplets seen on microscopy result from the increases in cholesterol esters (Fig 5). The biochemical nature of the lipid droplets remains to be established, however, and subcellular fractionation might clarify at which site cholesterol esters accumulate. It is known that changes in cholesterol ester content cause membrane perturbations and change permeability of model membranes. ${ }^{37}$ Many functions of the pancreatic acinar cell (including digestive enzyme synthesis, transport, storage, and secretion) are dependent upon the intact functioning of cellular membranes. The mechanism of cholesterol ester accumulation in acinar cells of alcoholic or malnourished rats is unknown. Wilson et al suggested that longterm ethanol feeding would cause pancreatic cholesterol ester accumulation by affecting exchange of cholesterol between serum and pancreatic tissue, ${ }^{38}$ and it is well known that cholesterol uptake by the cell stimulates acyl-CoA cholesterol-acyltransferase (ACAT) activity producing cholesterol ester. ${ }^{39} 40$ This proposed mechanism is in agreement with our data, because serum cholesterol concentrations of rats with pancreatic steatosis (groups C, D, and $E$ ) were higher than those in rats with normal pancreatic morphology (groups $\mathrm{A}$ and B) (Table IV).

TABLE $\mathrm{V}$ Effect of the five diets on amylase and lipase activity in pancreatic tissue

\begin{tabular}{|c|c|c|c|c|c|}
\hline & $\begin{array}{l}\text { Ad libitum } \\
(A)\end{array}$ & $\begin{array}{l}\text { Control } \\
35 \% \text { lipids (B) }\end{array}$ & $\begin{array}{l}\text { Alcoholic } \\
35 \% \text { lipids (C) }\end{array}$ & $\begin{array}{l}\text { Control } \\
5 \% \text { lipids (D) }\end{array}$ & $\begin{array}{l}\text { Alcoholic } \\
5 \% \text { lipids (E) }\end{array}$ \\
\hline \multicolumn{6}{|l|}{ Amylase } \\
\hline (U/mg protein) $\dagger$ & $108 \cdot 5(14 \cdot 5)$ & $79 \cdot 2(14 \cdot 8)$ & $15 \cdot 3(2 \cdot 9)$ & $8 \cdot 5(5 \cdot 4)$ & $2.9(1.3)$ \\
\hline$\underset{\text { Lipase }}{\left(\mathrm{U} \times 10^{2} / \mathrm{g} \text { pancreas }\right) \dagger}$ & $219 \cdot 1(35 \cdot 4)$ & $150 \cdot 5(29 \cdot 9)$ & $29 \cdot 4(6 \cdot 7)$ & $12 \cdot 9(8 \cdot 9)$ & $4 \cdot 5(2 \cdot 0)$ \\
\hline \multicolumn{6}{|l|}{ Lipase } \\
\hline$\left(\mathrm{U} \times 10^{2} / \mathrm{g}\right.$ pancreas $) \ddagger$ & $65 \cdot 8(12 \cdot 9)$ & $61 \cdot 1(6 \cdot 1)$ & $105.5(16.5)$ & $14 \cdot 0(4 \cdot 1)$ & $31.7(9 \cdot 4)$ \\
\hline
\end{tabular}

*Values are mean (SD) for 11 animals of group $A$ and seven animals of groups B, C, D, E.

tEthanol effect: $B-C, p<0.05$; malnutrition effect: $B-D, p<0.05$; solid diet effect: $A-B, p<0.05$

$\ddagger$ Ethanol effect: B-C, D-E, p $<0 \cdot 05$; malnutrition effect: B-D, C-E, $p<0 \cdot 05$. 


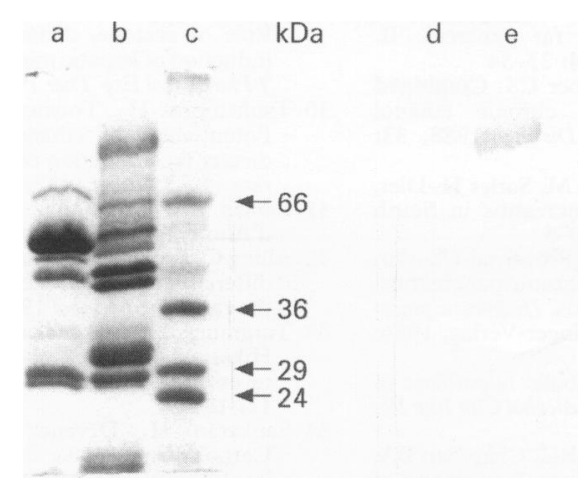

Figure 7: (Left), SDS-PAGE of human and rat pancreatic juices. Samples were collected as described in methods, lyophilised, resuspended in phosphate buffered saline pH 7.2 and analysed on $12 \%$ polyacrylamide gel stained with Coomassie: (a) rat pancreatic juice $(19 \mu \mathrm{g}$ of protein) (b) human pancreatic juice (32 $\mu \mathrm{g}$ of protein), (c) molecular weight markers. (Right), nitrocellulose replica of the same samples immunostained with pAs L64: (d) rat pancreatic juice, (e) human pancreatic juice.

Additional factors other than hypercholesterolaemia might also determine cholesterol ester deposition in acinar cells because their accumulation is not well correlated with serum cholesterol values (Table III, Table IV) and steatosis in alcoholic rats is also present without hypercholesterolaemia as has been reported by Tsukamoto et al. ${ }^{30}$ One such factor could be the metabolism of ethanol inside acinar cells inducing cholesterol ester formation. The pancreas metabolises ethanol through a non-oxidative pathway to form fatty acid ethyl esters, the esterification products of ethanol with various fatty acids. ${ }^{41-43}$ In addition, intracellular hydrolysis of fatty acid ethyl esters releases free fatty acids, which are preferentially incorporated into cellular cholesterol esters by ACAT. ${ }^{44}$ Pancreatic lipase has been shown to synthesise fatty acid ethyl esters. ${ }^{36}$ Therefore increased lipase activity in alcoholic rats (Table $\mathrm{V}$ ) could be an additional factor responsible for accumulation of cholesterol esters. Recently, ACAT has been cloned and northern blot analyses in human tissues showed the highest values of transcripts in the pancreas. ${ }^{45}$ This finding emphasises the importance of ACAT in lipid deposition in acinar cells.

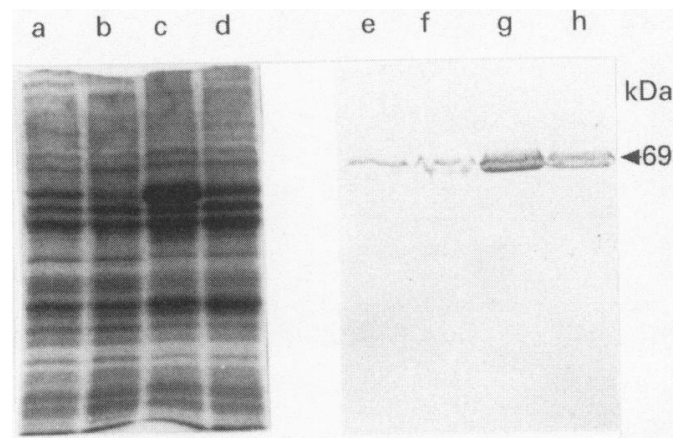

Figure 8: (Left), SDS-PAGE of rat pancreatic tissue: (a) rat pancreas of group $D,(b)$ rat pancreas of group $E$, (c) rat pancreas of group $B$, (d) rat pancreas of group $C$. Each sample lane contained $42 \mu \mathrm{g}$ of protein. (Right),

nitrocellulose replicas of the same samples immunostained

with $\mathrm{p}$ As L64. Molecular weight was determined by comparison with commercial standards (Dalton Mark VII-L, Sigma).

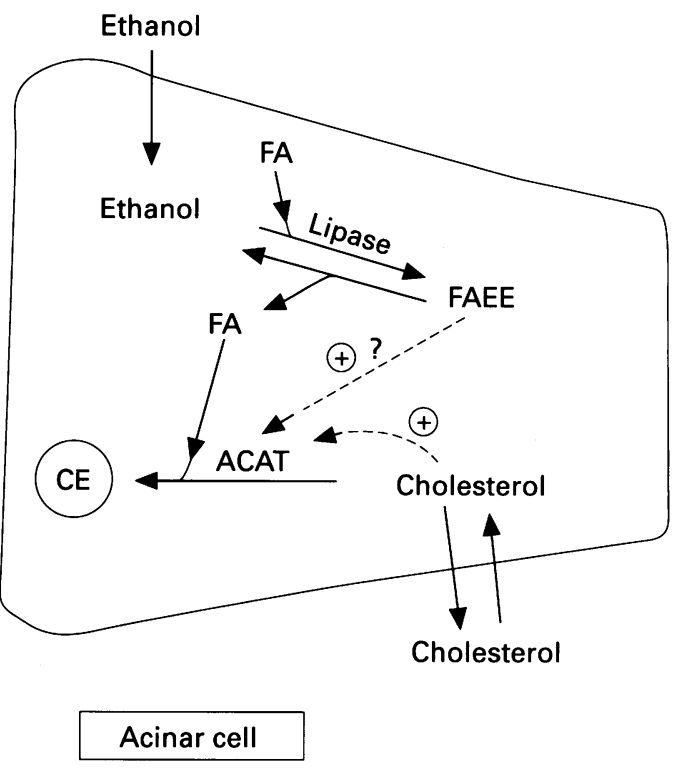

Figure 9: Model for cholesterol ester deposition in acinar cells. Longterm ethanol intake or malnutrition, or both, causes increased serum cholesterol concentrations

(hypercholesterolaemia). Cholesterol uptake by pancreatic acinar cells stimulates ACAT activity promoting cholesterol ester accumulation (lower pathway). On the other hand, ethanol is metabolised intracellularly by a non-oxidative pathway mediated by lipase. Fatty acid ethyl esters

(FAEE) formed are hydrolysed to free fatty acids (FA), which are preferentially incorporated into cellular cholesterol esters by ACAT (upper pathway). Stimulation of $A C A T$ activity by FAEE is suggested.

Based on our data and previous studies ${ }^{38} 44$ we propose two related pathways for cholesterol ester accumulation in the acinar cell (Fig 9): (a) hypercholesterolaemia, induced by malnutrition or longterm ethanol feeding, would cause increased cholesterol concentrations inside acinar cells producing ACAT stimulation and (b) esterification of free fatty acid with ethanol by a non-oxidative pathway mediated by lipase would induce incorporation of fatty acids into cholesterol esters. Further studies are necessary to prove these hypotheses, which could explain the development of pancreatic steatosis in the rat.

We are grateful to Dr J C Fernández-Checa and $\mathrm{Dr} T \mathrm{~T}$ Osborne for helpful discussions and comments on the manuscript and Dr Lombardo for providing cholesterol esterase polyscript and Dr Lombardo for providing cholesterol esterase polyassistance in electron microscopy.

This work was supported by grants from FISss (Ministerio de Sanidad y Consumo, España) 90/761 and 93.1222.

1 Sarles H. An international survey on nutrition and pancreatitis. Digestion 1973; 9: 389-403.

2 Sarles H, Cros RC, Bidart JM and The international group for the study of pancreatic diseases. A multicenter inquiry into the etiology of pancreatic diseases. Digestion 1979; 19: $110-25$.

3 Pitchumoni CS, Sonnenshein M, Candido FM, Panchacharam P, Cooperman JM. Nutrition in the pathogenesis of alcoholic pancreatitis. Am $\mathcal{J}$ Clin Nutr 1980; 33: genesis

4 Pitchumoni CS. Pancrease in primary malnutrition disorders. Am F Clin Nutr 1973; 26: 374-9.

5 Barbezat GO. The exocrine pancreas and protein-caloric malnutrition. Research Forum University of Cape Town, 1966. Tydskrif vor Geneeskunde 1967, 84-5.

6 Montealegre A, Sarles H, Ricosse JH, Sahel J. Pancreatic lesions due to prolonged malnutrition in Ibo children: possible transition between kwashiorkor and chronic calcifying pancreatitis. Pancreas 1987; 2: 114-6.

7 Pitchumoni CS, Thomas E. Chronic cassava Toxicity: possible relationship to chronic pancreatic disease in malnourished populations. Lancet 1973; ii: 1397-8.

8 Weisblum B, Herman L, Fitzegerald PJ. Changes in pancreatic acinar cells during protein deprivation. $f$ Cell Biol 1962; 12: 313-28. 
9 Tasso F, Clop J, Sarles H. The interaction of ethanol, dietary lipids and proteins on the rat pancreas. II Ultrastructural study. Digestion 1971; 4: 23-34

10 Wilson JS, Korsten MA, Leo MA, Lieber CS. Combined effects of protein deficiency and chronic ethanol consumption on rat pancreas. Dig Dis Sci 1988; 33. $1250-9$.

11 Balakrishnan V, Sauniere JF, Hariharan M, Sarles H. Diet, pancreatic function, and chronic pancreatitis in South pancreatic function, and chronic pancreati

12 Multigner L, De Caro A, Montatto G, Provansal-Cheylan $M$, Sarles H. Biochemical markers of chronic pancreatitis. In: Malfertheiner P, Ditschumert H, eds. Diagnostic procedures in pancreatic diseases. Berlin: Springer-Verlag, 1986: 208-14

13 Dreiling DA, Bordalo O. A toxic-metabolic hypothesis of pathogenesis of alcoholic pancreatitis. Alcohol Clin Exp Res 1977; 1: 293-9.

14 Wilson JS, Colley PW, Sosula L, Pirola RC, Chapman BA Somer JB. Alcohol causes a fatty pancreas. A rat model of ethanol-induced pancreatic steatosis. Alcohol Clin Exp Res 1982; 6: 117-21

15 Simsek A, Singh M. Effect of prolonged ethanol intake on pancreatic lipids in the rat pancreas. Pancreas 1990; 5: $401-7$.

16 Lieber CS, De Carli LM. The feeding of ethanol in liquid diets: 1986 update. Alcohol Clin Exp Res 1986; 10: 550-3.

17 Laemmli UK. Cleavage of structural proteins during the assembly of the head of bacteriophage T4. Nature 1970 227: $680-5$.

18 Doumas BT, Waston WA, Biggs HG. Albumin standards and the measurement of serum albumin with bromocresol green. Clin Chim Acta 1971; 31: 87-96.

19 Fossati P, Precipe L. Serum triglycerides determined colorimetrically with an enzyme that produces hydrogen peroxmetrically with an enzyme that produc
ide. Clin Chem 1982; 28: $2077-80$.

20 Allain CC, Poon LS, Chan CSG, Richmond W, Fu PC. Enzymatic determination of total serum cholesterol. Clin Chem 1974; 20: 470-5.

21 Sarber RL, Livshin L, Rasmussen J, Blair HE. Rapid measurement of serum amylase with a stable chromogenic substrate. Clin Chem 1986; 32: 1136.

22 Ziegenhorn J, Neumann U, Knitsch KW, Zwez W. Determination of serum lipase. Clin Chem 1979; 25: 1067

23 Lowry OH, Rosebrough NJ, Farr L, Randall RJ. Protein measurement with the Folin phenol reagent. $f$ Biol Chem 1951; 193: 265-75.

24 Folch J, Lees M, Sloane Stanley GH. A simple method for the isolation and purification of total lipids from animal tissues. I Biol Chem 1980; 226: 231-9.

25 Rudel LL, Morris MD. Determination of cholesterol using o-phthalaldehyde. $\mathcal{F}$ Lipid Res 1973; 14: 364-6.

26 Fiske $\mathrm{CH}$, Subbarow Y. The colorimetric determination of phosphorus. F Biol Chem 1925; 66: 375-400.

27 Alfin-Slater RB, Aftergood L. Essential fatty acids reinvestigated. Physiol Rev 1968; 48: 758-68.

28 Rafael J, Patzelt J, Elmodfa I. Effect of dietary linoleic acid and essential fatty acid deficiency on resting metabolism, nonshivering thermogenesis and brown adipose tissue in the rat. $\mathcal{F}$ Nutr 1988 ; 118 : $627-32$.
29 Lieber CS, Lasker JM, De Carli LM, Saeli J, Wojtowicz T. Role of acetone, dietary fat and total energy intake in induction of hepatic microsomal ethanol oxidizing system. f Pharmacol Exp Ther 1988; 247: 791-5.

30 Tsukamoto H, Towner SJ, Yu GSM, French SW. Potentiation of ethanol-induced pancreatic injury by dietary fat. Induction of chronic pancreatitis by alcohol in rats. Am $\mathcal{F}$ Pathol 1988; 131: 246-57.

31 Panlab SA. Barcelona: Technical report U.A.R. (Usine d'Alimentation Rationnelle) 1993.

32 Alling C, Bruce A, Karlsson I, Svennerholm L. The effect of different dietary levels of essential fatty acids on growth of the rat. Nutr Metabol 1974; 16: 38-50.

33 Tanimura $H$, Takenaka $M$, Setoyama $M$, Nagase $M$, Hikasa Y. Pathogenesis and treatment of pancreatitis due to essential fatty acid deficiency. Gastroenterol $\mathfrak{J p n} \mathbf{1 9 7 7}$ 12: 484-9.

34 Sankaran H, Deveney CW, Larkin EC, Rao GA Carbohydrate intake determines pancreatic acinar amylase activity and release despite chronic alcoholemia in rats. F Nutr 1992; 122: 1884-91.

35 Ponnappa BC, Hoek JB, Sarchet K, Rubin E. Dietary carbohydrate level determines the effect of long-term ethanol ingestion on rat pancreatic amylase content. $f \mathrm{Lab}$ Clin Med 1986; 107: 556-62.

36 Riley DJS, Kyger EM, Spilburg CA, Lange LG. Pancreatic cholesterol esterases. 2. Purification and characterization of human pancreatic fatty acid ethyl ester synthase. Biochemistry 1990; 29: 3848-52.

37 Forrest BJ, Cushley RJ. Cholesterol esters and membrane permeability, a nuclear magnetic resonance study. Atherosclerosis 1977; 28: 309-18.

38 Wilson JS, Somer JB, Pirola RC. Chronic ethanol feeding causes accumulation of serum cholesterol in rat pancreas. Exp Mol Pathol 1984; 41: 289-97.

39 Goldstein JL, Brown MS. The low density lipoprotein pathway and its relation to artherosclerosis. Annu Rev Biochem way and its relation to

40 Chang CCY, Chang TY. Cycloheximide sensitivity in regulation of acyl coenzyme A: cholesterol acyltransferase activity in chinese hamster ovary cells. 2 . Effect of stero endogenously synthesized. Biochemistry 1986; 25: 1700-6.

41 Laposata EA, Lange LG. Presence of nonoxidative ethano metabolism in human organs commonly damaged by ethanol abuse. Science 1986; 231: 497-9.

42 Hamamoto T, Yamada S, Hirayama C. Nonoxidative metabolism of ethanol in the pancreas; implication in alcoholic pancreatic damage. Biochem Pharmacol 1990; 39: 241-5.

43 Manautou JE, Carlson GP. Ethanol-induced fatty acid ethyl ester formation in vivo and in vitro in rat lung. Toxicology 1991; 70: 303-12.

44 Laposata EA, Harrison EH, Hedberg EB. Synthesis and degradation of fatty acid ethyl esters by cultured hepatoma cells exposed to ethanol. F Biol Chem 1990; 265 : 9688-93.

45 Chang CCY, Huh HY, Cadigan KM, Chang TY. Molecular cloning and functional expression of human acyl-coenzyme A: cholesterol acyltransferase cDNA in mutant chinese hamster ovary cells. F Biol Chem 1993; 268: 20747-55. 